Meta

Journal des traducteurs

Translators' Journal

\title{
Client Relations
}

\section{R. Clive Meredith}

Volume 25, numéro 3, septembre 1980

URI : https://id.erudit.org/iderudit/003638ar

DOI : https://doi.org/10.7202/003638ar

Aller au sommaire du numéro

Éditeur(s)

Les Presses de l'Université de Montréal

ISSN

0026-0452 (imprimé)

1492-1421 (numérique)

Découvrir la revue

Citer cet article

Meredith, R. C. (1980). Client Relations. Meta, 25(3), 303-309.

https://doi.org/10.7202/003638ar

Ce document est protégé par la loi sur le droit d'auteur. L'utilisation des services d'Érudit (y compris la reproduction) est assujettie à sa politique d'utilisation que vous pouvez consulter en ligne.

https://apropos.erudit.org/fr/usagers/politique-dutilisation/
Cet article est diffusé et préservé par Érudit.

Érudit est un consortium interuniversitaire sans but lucratif composé de l’Université de Montréal, l'Université Laval et l'Université du Québec à Montréal. Il a pour mission la promotion et la valorisation de la recherche. https://www.erudit.org/fr/ 


\section{Client Relations}

R. Clive Meredith

\section{INTRODUCTION}

An article of this kind in a review such as Meta might well be seen as a sermon to the converted. Few indeed are the professional translators who have not had to grapple with the problems raised here. Meta, however, is not read only by translators: it reaches all kinds of people interested in the profession of translation - maybe even the representatives of some of our clients - who perhaps are not as aware as they should be of everything the practice of that profession involves.

The problems discussed here are real. In more than one instance they have contributed toward professional demotivation. I feel it is time they were aired fully in public and if, in doing so, I can bring about just one "Damascus incident", my time will not have been wasted.

When your friendly neighbourhood physician finds you over-wrought and prescribes, say, ten milligrams of Valium, t.i.d. before rush jobs, who are you to change the " 10 " on the prescription form to " 20 ", even if it means altering only one figure? When it's thirty below and the furnace conks out, a qualified specialist is called in to do what's necessary: no one in his right mind will dare instruct that specialist on how to do his work, or try to re-do what's been done after the job is finished.

Indeed, most qualified practising professionals are refreshingly free from client interference in the practice of their profession. Summoned in a moment of need, they do what's required of them, and their expertise is relied on. Why can the same not be said of translators?

Client mistrust - or I should say manifestation of that mistrust - is the translator's nightmare. I have no knowledge of what goes on in this regard in private enterprise, but I can with perfect justification say that this practice has been known to occur in the Québec Civil Service. A popular myth among clients holds that as long as a person has any knowledge at all of the target language, he is eminently qualified to take all the liberties he wants with a text which has been worked and reworked by persons whose competence in their field has long been proven. And yet it happens regularly. The scenario is roughly 
this: a translation is done by a quali\&ed translator, and revised by another of equal, or superior, competence. With translator and revisor congratulating each other on a good job, the text is sent off for publication, distribution at an important conference, or whatever. When the printed copy is returned to the translator, it is not unusual to see that his careful, painstaking craftsmanship has been brought to naught by totally needless intervention. Not only is the translation irreperably damaged, but the translator's outside reputation - and by extension his colleagues' - suffers. And through no fault of his: merely because some self-important critic has overrated his own ability as a linguist and taken it upon himself to "improve" the text. In a number of cases, this happens without so much as a "by-your-leave". Also, incredible as this may sound, most of the time the critic's mother tongue is not the target language. For him to act in such a manner, then, requires a massive dose of either naiveté or self-confidence, and most of the cases of this kind with which I have been acquainted seem to reflect the former rather than the latter. Somehow, the eminently logical notion of discussion - getting together with the translator and talking over proposed changes before they are actually made - seems completely foreign to these interventionists.

Then, of course, there are cases like this one, to which I was privy: A client, who had a number of "improvements" to propose for a translation he'd requested, summoned the translator to discuss them. Agreement was reached between client and translator on every single point, and the translator took his leave convinced that the only changes made to the text would be those agreed to between him and his client. Imagine his feelings, then, when he saw the translation in print: the client had completely disregarded all the points raised by the translator, and had reinserted his own "improvements". Many of these were grammatical errors, and reduced the text to nonsense.

Sometimes we wonder what we're doing in the job.

I could name names and date dates to bear out my points, but that might not be considered cricket (besides, I have a healthy respect for the libel laws). I can, however, provide, and attest to the veracity of, the following examples:

(i) (a) source text

...la destination d'un navire au moment où il prend la mer est déterminée par les usages maritimes.

translation

...the destination of a ship is known from the time it leaves port and is determined in accordance with marine usage.

"improvement"

...the destination of a ship is known from the time he leaves port and is...

(b) source text

S'il s'agit d'un contrat et que la valeur de ces facultés... à la mise en risque était de huit cents dollars...

translation

If the contract involved is a non-valued contract and the value of these goods... at the time the contract was entered into was eight hundred dollars... 
"improvement"

If the contract involved is a non-valued contract and that the value of the goods...

(ii) (a) source text

...la réglementation découlant de la nouvelle loi devrait être connue, et bien connue, du public, le plus près possible du moment où la loi est adoptée.

translation

...any regulation made under new legislation sould be publicized as well as possible, and as soon as possible after the legislation is passed.

"improvement"

...any regulation make under new legislation should be publicized and wellknown by the public as well as possible, as soon as possible after the legislation is passed.

(b) source text

Certains fonctionnaires m'ont fait part de leurs réflexions concernant... translation

Certain government officials expressed to me their reflections on...

"improvement"

Certain government officials expressed to me their deep concern reflections on...

There is a second danger inherent in this type of unilateral change: If the client decides, for example, that what started out as a singular subject should for reasons best known to himself - be a plural subject, will he remember to make all the corresponding changes to tense, number and so on which necessarily follow from his first change? I doubt it - even some qualified revisors occasionally slip on this one.

Very occasionally, a client will send along a text which he himself has translated, with a request that we merely look over the text to ascertain that it reads well. This happens rarely indeed, but whenever it does, we almost invariably wish the request had been for a straightforward translation! A group of lawyers once had a hand in preparing an important report for the government, the translation of which I was asked to revise. The author of one segment of that report offered to translate that segment himself "to spare you the trouble. All it needs is a glance - I'm sure it's all right'. It got the glance, and the glance led to a re-write. Ironically enough, one passage in that text read as follows:

The translation of a foreign decision may be certified as correct by... any person authorized for this purpose...; this includes lawyers who... in general translate better than any other competent authority.

Self-confidence, or naïveté?

In checking translations, clients sometimes place just a little too much blind faith in the dictionary. We once worked on a text dealing with Christmas tree production. The translation presented no serious problems, and in due course was returned to the client and thought no more about. Some time later the translator who had worked on that particular assignment telephoned the client 
about something unrelated to the translation. "Oh, by the way", said Client, "I've made a few small changes to your text". It turned out that wherever the translation spoke of "Christmas trees" (in the plural), Client had brought the expression back to the singular. "What in the world for?" wondered Translator. "Because it's not written that way in my dictionary".

Where ignorance is bliss...

Then we have the client who, although he perhaps does not actively intervene in the translation process, still has a rather warped conception of what that process involves. As we know, it involves a number of phases: the text received is immediately given to a translator, whose first objective is to learn - in depth - what that text is all about. This of course requires a thorough reading of the text; as he reads, the translator makes notes: on terms to be researched, on phrases or words with double or doubtful meaning, and so on. This phase alone, depending on the length and nature of the source text, can occupy a fair amount of the translator's time. Only when he has read his text through and become acquainted with it does he begin the translation. Again, the amount of time it takes him to complete the job depends on a number of things: the technical nature of the text, the ease with which the author expresses himself, and so on. When he has finished the first draft, the translator should then allow ample time to re-read his text and polish it up. Once he's satisfied with it, the text is sent for revision. This is a necessary phase, which involves a close comparison of source and target texts by a second translator, who makes sure there have been no slips in the translation. Revision also provides a second opportunity for stylistic improvement. Next, translator and revisor discuss the major changes made by the revisor. When both are in agreement as to how the translation should read, it is given to a typist who prepares the final copy. The next step is copy-correction. Once all the typographical errors have been corrected - and depending on the time remaining, the relative importance of the text and the availability of staff - the translation is read one last time: a sort of "quality check".

Now all this takes time! And unfortunately, often through ignorance, clients do not grasp this, and often send texts for translation with very tight deadlines which they insist be respected. This increases stress all the way down the line: on translator, on revisor, on typist, on copy corrector and on support staff. In circumstances such as this, the finer points of style are perforce sacrificed in the interest of expediency, and the resulting product is merely good, while with a little more time - hence a little less stress - it could well be excellent. For some reason, the tightness of deadlines seems to vary in direct proportion to the importance of the text to be translated. And more's the pity. I call to mind a series of questions and answers on a very important question, with which we were asked to deal in a very short space of time; the translation was to be published in a learned journal. I find it hard to believe that the source text had not been prepared at least a couple of days before it was sent for translation "à la course". Had the team assigned to that particular job been given just that much more time (sometimes half a day is all it takes), that translation would truly have been a credit to the client. 
And how often do we find ourselves in this situation: a text is sent for translation which will be read as a speech the next day (always the next day !). The work is tackled with due diligence, and just as we're getting to the copycorrection stage, the phone rings: all engines stop. Go no further. The author has practically re-written the text. We wait - and wait - and eventually the new text arrives. If indeed it is completely new, there's no problem, at least relatively speaking: the whole thing is re-translated. If there are changes to be made here and there, however (words, sentences or paragraphs added or deleted), the client can do a real service by indicating precisely where those changes can be found. Otherwise the text will have to be compared in extenso with the one received first, a process which can be quite time-consuming.

And we're no strangers to this situation: Client phones in a highly nervous state: at noon - no later - we'll be receiving a text of X pages which he will need - sans faute - the following morning at 9:00. We agree to help him out (indeed, in many cases we've no choice). Noon comes, though, then 2:00, then 4:00, then text. Another evening shot...

And this (to use an "in" word) scenario: Extremely Concerned Client phones to say that the translation we're doing for him has just "become urgent". Can we finish it by the end of the day? He is given the necessary assurances, and we promise to telephone him the minute the translation is ready, so he can send someone down to collect it. Answer: "You people are wonderful. That really saves my neck. I'll come down myself'. The panic button is sat on not just pushed - for the rest of the day, and Client finally gets the promised phone call. Answer: "Oh, it's not that urgent. I'll send someone down around noon tomorrow".

Consider next the client working in a highly-specialized field, who requests a translation of a learned paper his is preparing. His office walls are doubtless lined with books, often in the language of the translation, which could be of invaluable assistance to the translator from a terminological point of view. Seldom, though, if ever, does this seem to register with the client. He merely sends the text along, and we have to do the research. To be sure, terminological research fills a sizeable part of any translator's work-day, but if the assignment comes complete with tight deadline, the hours spent on research can't be devoted to the niceties of language, and again the text could suffer - and perhaps not only stylistically: the translator's research will likely turn up a number of proposed translations for any given term. Not being as conversant with the specialty as he might, the translator could well opt for one which, while not wrong, is simply not the properly accepted translation. Had the client taken the necessary trouble, the result would have been just that much better, and the translator would have acquired just that much more knowledge. I remember being presented with a text which dealt with auto mechanics - decidedly not my field. It was highly technical, with two or three specialized terms on every line, droned on for a number of pages, and was wanted in some incredibly short period of time. In ordinary circumstances I would have had to spend the better part of the night searching high and low for the proper English translation 
of all those terms. In this case, however, the client had foreseen that there might be translation problems, and had provided the accepted translation of every single term, in pencil, in the space above on the source text. Good thinking! The translation was finished in a day.

Then there's the client who, in all good faith, telephones to ask one question: he as a twenty-five page text which must be translated. How long will the job take? A simple question to him, but one that in reality it's almost impossible for the translator to answer on the spur of the mopment, unless he has certain information: are those pages short or long? single or double-spaced? Is the text full of technical terms, chemical equations and mathematical formulae? Is it full of illustrations? Are there quotations? If so, where from? Do translations of those "quotes" exist, or will we have to provide our own? If they exist, where can they be found? And so on. These clients are generally advised to send us the text. We'll examine it, then be in a better position to give them a more accurate time estimate.

Be all this griping as it may, the client naturally remains a vital part of the life of any translator - in a sense, his very raison d'etre. And to be fair, the vast majority of our clients do in fact appreciate what we are doing, and understand the problems we face. Witness those - the serious ones - who take the time to fill out the appraisal forms sent along with each translation, providing much-valued apoinions as to the quality of our work. The matter of "client education", however, does persist, and remains a most frustrating one. Each client representative who deals with us must be informed of the requirements of the office, the forms to be filled out (and how they should be filled out) before a translation can be done, the number of copies we require of the source text, and so on. If the client's demands are unreasonable, we must patiently explain to him why they cannot be met, and propose compromise measures; sometimes we are forced to pester him for information which - were he aware of our requirements - he would automatically forward along with the source text. Happily, we have seen this form of friendly persuasion pay off in a number of instances: the client comes to realize that we aren't merely agents for some translating computer, but professionals who require certain basic tools if they are to do their job well. His eyes, in short, are opened, and we rejoice. Then what happens? The convert is transferred, pensioned off, or whatever, and the whole process must begin anew with his successor. I see no way out of it: as long as there are translators, there will be clients to educate.

To conclude, may I offer the following as the client's way to his translator's heart? Proper respect for these requirements could indeed make life easier for both parties.

1. Don't set impossible deadlines. Try to plan ahead. If your text is genuinely urgent, and your request sufficiently justified - and it is physically possible to do the translation within the time period mentioned - it can probably be done. But remember what has been said about the various stages of translation. 
2. If you have promised that a text will be ready for translation by a certain time, try to see that it is. Put yourself in the place of a translator to whom you've promised to give an assignment at 2:00. He cancels a whole series of other jobs so he'll be ready to start working immediately for you, then only receives the text at suppertime...

3. If you have any material which might be of use to the translator, send it, along with the source text. For instance, if the source text contains translations of quotations which were originally written in the target language, make photos of the appropriate passages and enclose them. We are sometimes asked to translate captions for slide presentations, photographs, and the like. Why not send us the slides or photos too, or arrange for the translator in question to view them in your office? If your text quotes a passage from a work whose translation is known to exist, indicate where in that work the passage is to be found; this greatly facilitates tracking down the recognized translation: Recently I was required to translate a document which quoted half a sentence from the Québec Government's White Paper on Cultural Development. No indication was given as to where in the White Paper those three lines might be hiding. Now that White Paper is long - two volumes' worth - and set in fairly small print. As I was starting to comb the text, a colleague dropped by, who had worked on the translation. Acting on a hunch, she soon found what I was seeking. My colleague, however, had the advantage of having worked on the translation of the White Paper, whereas I scarcely knew the text. Had she not come along, I might be searching still.

4. Before making any changes to the text of a translation, and this applies doubly if the target language is not your own, contact the translator and/or the revisor. Arrange to meet him or them, and allow ample time to discuss the changes you'd like to see made (for obvious reasons it's preferable not to carry on this type of discussion by phone). Maybe you spotted some mistakes. Errare, after all, humanum est, and no translator worthy of the title will resent having his mistakes pointed out to him. But please - in your interest as well as the translator's - no unilateral acts. They have a habit of bouncing back, sometimes with a dreadful vengeance. 